\title{
Implications Test of Temperature, Rainfall and Carbon Dioxide Combinations on Indian Mustard Using Multi Crop Simulation Models for Western Haryana, India
}

\author{
Divesh Choudhary", Raj Singh, C.S. Dagar, and Anil Kumar
}

Department of Agricultural Meteorology, Chaudhary Charan Singh Haryana Agricultural University, Hisar-125 004, Haryana, India

*Corresponding author

\section{Keywords}

InfoCrop, WOFOST validation, Sensitivity analysis, Temperature, $\mathrm{CO}_{2}$ mustard

Article Info

Accepted:

10 January 2018

Available Online:

10 February 2018

A B S T R A C T

The sensitivity analysis of three Brassica spp. (cv. RH30, Laxmi and RH0749) cultivar of wheat was performed to see the possible change in the grain yield due to change in weather $\left(\mathrm{T}_{\max }, \mathrm{T}_{\min }\right.$ and rainfall) and non-weather parameters $\left(\mathrm{CO}_{2}\right)$ using InfoCrop and WOFOST model. The potential condition was assumed with congenial weather and adequate management practices. The higher per cent of benefits was obtained at $500 \mathrm{ppm}$ but further increase in $\mathrm{CO}_{2}(550,600,650$ and $700 \mathrm{ppm})$ combined with one unit increase in mean ambient temperature reduced the percent change in mustard yield. The interaction effect of temperature and $\mathrm{CO}_{2}$ concentration revealed that the response of variety Laxmi was quite higher followed by $\mathrm{RH} 0749$ and $\mathrm{RH} 30$. At highest $\mathrm{CO}_{2}$ concentration (700 $\mathrm{ppm}$ ), the negative impact of temperature was simulated only at $-1^{\circ} \mathrm{C}$ in all the mustard varieties. Under increasing of $20 \%$ rainfall scenario, the increase in the yield levels are higher in RH 0749 followed by Laxmi and RH 30 using both crop simulation models. The higher benefits was obtained at $+20 \%$ rise in rainfall but further decrease or increase $(-30$ to $-10 \%$ and +30 to $+40 \%$ ) in rainfall combined with change in mean ambient temperature \pm 3 to $\pm 5^{\circ} \mathrm{C}$ reduced the percent change in mustard yield. The interaction effect of temperature and rainfall change revealed that the response of RH 0749 variety was quite higher followed by RH 30 and Laxmi.

\section{Introduction}

Current global climate models predict a mean increase in temperature of $1.0-3.7{ }^{\circ} \mathrm{C}$ with greater likelihood of increased frequency of heat waves with variable precipitation patterns over most land areas by the mid- to late twenty-first century (IPCC, 2013). The higher greenhouse gases could leads to vagaries in regional and seasonal climate patterns during coming century (Gates et al., 1992). Tropical countries are more vulnerable to climatic effects in agricultural productivity. Simulation models provide a scientific approach to study the impact of climate change on agricultural production and world food security. Crop simulation modeling has the capability of forecast yield levels based on the prevailing weather conditions and past production records. Crop growth simulation models are 
quantitative tool based on scientific knowledge that can evaluate the effect of climatic, edaphic, hydrological and agronomic factors on crop growth and yield.

Mustard crop is highly vulnerable, particularly in the semi-arid and arid regions of India. The climate is warming through the processes such as $\mathrm{CO}_{2}$ and changed pattern of temperature and precipitation resulting in heat and drought stresses, respectively (Ram Niwas and Khichar, 2016). Sensitivity test of the crop simulation models is the process by which various input parameters are evaluated with regard to their importance relative to simulation relations. Catalin et al., (2009) validated the WOFOST model from crop growth monitoring system (CGMS) for Romania and checked the adaptability for the climate change study for winter crops mainly for cereals. They validated the WOFOST and Crop Growth Monitoring System (CGMS) and found that these were interesting tools for study the plant-soil-atmosphere interactions. InfoCrop model simulated yield of mustard was found to be sensitive to changes in the atmospheric concentration of $\mathrm{CO}_{2}$ and temperature and mustard yield was increased with elevated $\mathrm{CO}_{2}$ concentration, while the positive effect of increased $\mathrm{CO}_{2}$ was nullified by temperature rise and (Bhoomiraj et al., 2010) also found that the rainfed conditions crop was found to be more susceptible to changing climate in north India due to projected reduction in rainfall in future scenarios. Bhaskaran et al., (1995) used the UKMO GCM model which was predicted that with elevated $\mathrm{CO}_{2}$ concentration, approximately $20 \%$ increase in total precipitation occurs in winter or rabi crop seasons.

In general, it is evident that many $\mathrm{C}_{3}$ crops, in the absence of biotic (pests, diseases and weeds) or abiotic (water and nutrients) stresses will be able to capitalize on elevated $\mathrm{CO}_{2}$ and convert it into photosynthates and consequently improved growth and yield (Ainsworth and Rogers, 2007; Leakey et al., 2009). The effect of low temperature (frost) during podding and seed development stage in mustard causes freezing injury in seeds and sizable reduction in seed yield (Ram Niwas and Khichar, 2016), whereas Rise in atmospheric temperature reduced leaf area index, grain number as well as weight of grains which was in turn reflected in yield of mustard crop. Seed yield reduction occurred by low water availability during stem elongation, flowering and pod development in mustard. Fertilization effects on $\mathrm{CO}_{2}$ on crop production will be necessary in future climate change scenarios to offset the anticipated negative impacts of high temperature and to feed ever increasing human population (Ainsworth et al., 2008). Indian mustard suffers from exposure of low temperature during vegetative and early pod filling stage and relatively higher temperature during vegetative and early pod filling stage and relatively higher temperature during grain filling and maturity (Kumar et al., 2007; Adak et al., 2010).

\section{Materials and Methods}

The field experiments were conducted in two consecutive rabi seasons during 2012-13 and 2013-14 at the research farm of the Department of Agriculture Meteorology, CCS HAU, Hisar, India situated at latitude $29^{\circ} 10^{\prime}$ $\mathrm{N}$, longitude $75^{\circ} 46^{\prime} \mathrm{E}$ and at altitude of 215.2 $\mathrm{m}$ above mean sea level. The daily meteorological variables were collected from agrometeorological observatory situated near the experimental plot. The InfoCrop (v. 2.0.) and WOFOST ( $\mathrm{v}$ 7.1.7) model were calibrated and validated under three dates of sowing viz., $\mathrm{D}_{1}$ : Oct. 10, 2012 and Oct. 21, 2013; $\mathrm{D}_{2}$ : Oct. 25, 2012 and Oct. 30, 2013; and $\mathrm{D}_{3}$ : Nov. 8, 2012 and Nov. 10, 2013 by Choudhary et al., (2014) for cv. $\mathrm{V}_{1}$ : RH 30, $\mathrm{V}_{2}$ : Laxmi and $\mathrm{V}_{3}$ : 
RH 0749. To validate the models, same year weather (2012-13 and 2013-14) and soil files were used. The actual/base yield of mustard was used to compare with sensitivity analysis results. Here, an effort has been made to test the models under two situations in terms of mathematical logic and stability to extreme values of weather and non-weather parameters. The first situation is combined effect of change in mean ambient temperature $\left( \pm 1\right.$ to $\pm 5{ }^{\circ} \mathrm{C}$ ) and concentration of carbon dioxide (base value-360 ppm; 400, 450, 500, 550, 600, 650, and $700 \mathrm{ppm}$ ) and; second situation is combined effect of mean ambient temperature $\left( \pm 1\right.$ to $\left.\pm 5{ }^{\circ} \mathrm{C}\right)$ and change in rainfall $(-30$ to $+40 \%)$ from the normal value (Table 1). The models were simulated the mustard seed yields under altered weather and non-weather parameters.

\section{Results and Discussion}

Effect of mean ambient temperature and carbon dioxide

Sensitivity analysis was carried out for combined effect of change in mean ambient temperature and different levels of $\mathrm{CO}_{2}$ concentration $(400,450,500,550,600,650$ and $700 \mathrm{ppm}$ ) using InfoCrop and WOFOST models in Figures 1 and 2. The results revealed that $\mathrm{CO}_{2}$ concentration of $400 \mathrm{ppm}$ there was less reduction in seed yield either increased or decreased in mean ambient temperature $\left( \pm 1\right.$ to $\left.\pm 5^{\circ} \mathrm{C}\right)$ in all three mustard varieties with both the models. The desirable effects for InfoCrop model were simulated under downscaling of the temperature, the total effect being -22 to $26 \%$ (RH 30), -22 to $29 \%$ (Laxmi) and -25 to $24 \%$ (RH 0749), whereas, using WOFOST model, the effect was -28 to $19 \%$ (RH 30), -28 to $22 \%$ (Laxmi) and -31 to $20 \%$ (RH 0749), respectively. At $\mathrm{CO}_{2}$ concentration $450 \mathrm{ppm}$, using InfoCrop model the net effect on yield was -29 to $36 \%$ (RH 30), -31 to $36 \%$ (Laxmi) and -31 to $35 \%$ (RH 0749), however, the effect under using WOFOST model was -35 to $22 \%$ (RH 30), -33 to $25 \%$ (Laxmi) and -34 to $23 \%$ (RH 0749), respectively. Under increasing of $\mathrm{CO}_{2}$ concentration 500 ppm scenario, increased yield levels were higher in RH 30 followed by Laxmi and lowest in RH 0749 using these models. The higher benefits was obtained at $500 \mathrm{ppm}$ but further increase in $\mathrm{CO}_{2}$ (550, 600,650 and $700 \mathrm{ppm}$ ) combined with one unit increase in mean ambient temperature reduced the per cent change in mustard yield.

The interaction effect of temperature and $\mathrm{CO}_{2}$ concentration revealed that the response under variety Laxmi was showed high response followed by RH 0749 and RH 30. The per cent change in yield decreased in both ways i.e. either increasing or decreasing the mean ambient temperature from mean value.

Table.1 Base values and change in parameter values used in InfoCrop and WOFOST models for sensitivity analysis

\begin{tabular}{|l|l|l|}
\hline Parameters & Base values & $\begin{array}{l}\text { Change in parameter used in InfoCrop } \\
\text { and WOFOST model }\end{array}$ \\
\hline $\begin{array}{l}\text { Mean ambient } \\
\text { temperature }\left({ }^{\circ} \mathbf{C}\right)\end{array}$ & $\begin{array}{l}\text { Temperature of crop season } \\
2012-13 \& 2013-14\end{array}$ & \pm 1 to $\pm 5{ }^{\circ} \mathrm{C}$ \\
\hline Rainfall $(\mathbf{m m})$ & $\begin{array}{l}\text { Rainfall of crop season } \\
2012-13 \& 2013-14\end{array}$ & -30 to $+40 \%$ \\
\hline $\begin{array}{l}\text { Carbon dioxide } \\
(\mathbf{p p m})\end{array}$ & $360 \mathrm{ppm}$ & $400,450,500,550,600,650$, and $700 \mathrm{ppm}$ \\
\hline
\end{tabular}


Fig.1 Interaction effect of change in mean ambient temperature $\left({ }^{\circ} \mathrm{C}\right)$ and $\mathrm{CO}_{2}$ conc. $(\mathrm{ppm})$ on simulated mustard seed yield (\% change) using InfoCrop model

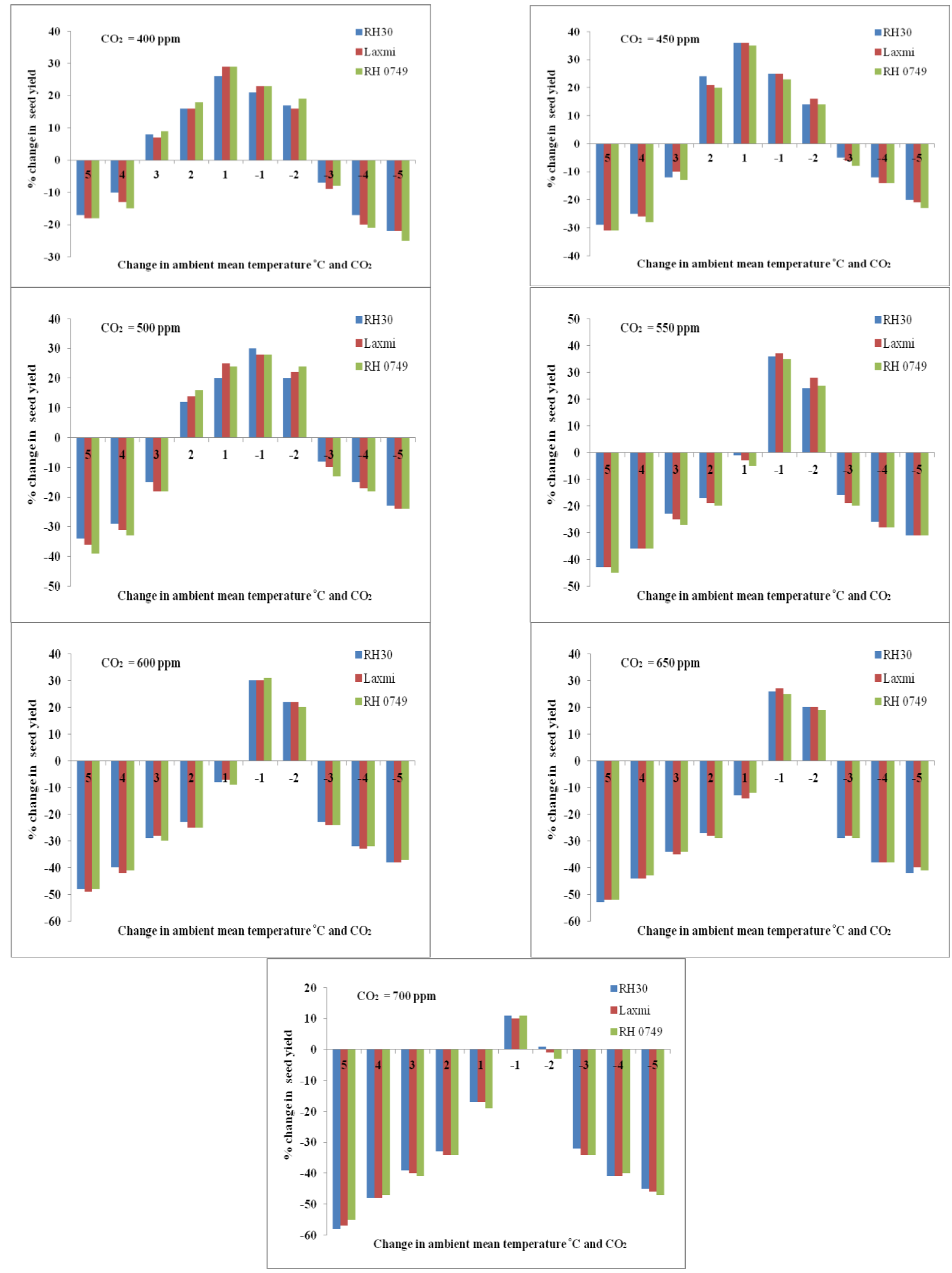


Fig.2 Interaction effect of change in mean ambient temperature $\left({ }^{\circ} \mathrm{C}\right)$ and $\mathrm{CO}_{2}$ conc. $(\mathrm{ppm})$ on simulated mustard seed yield (\% change) using WOFOST model

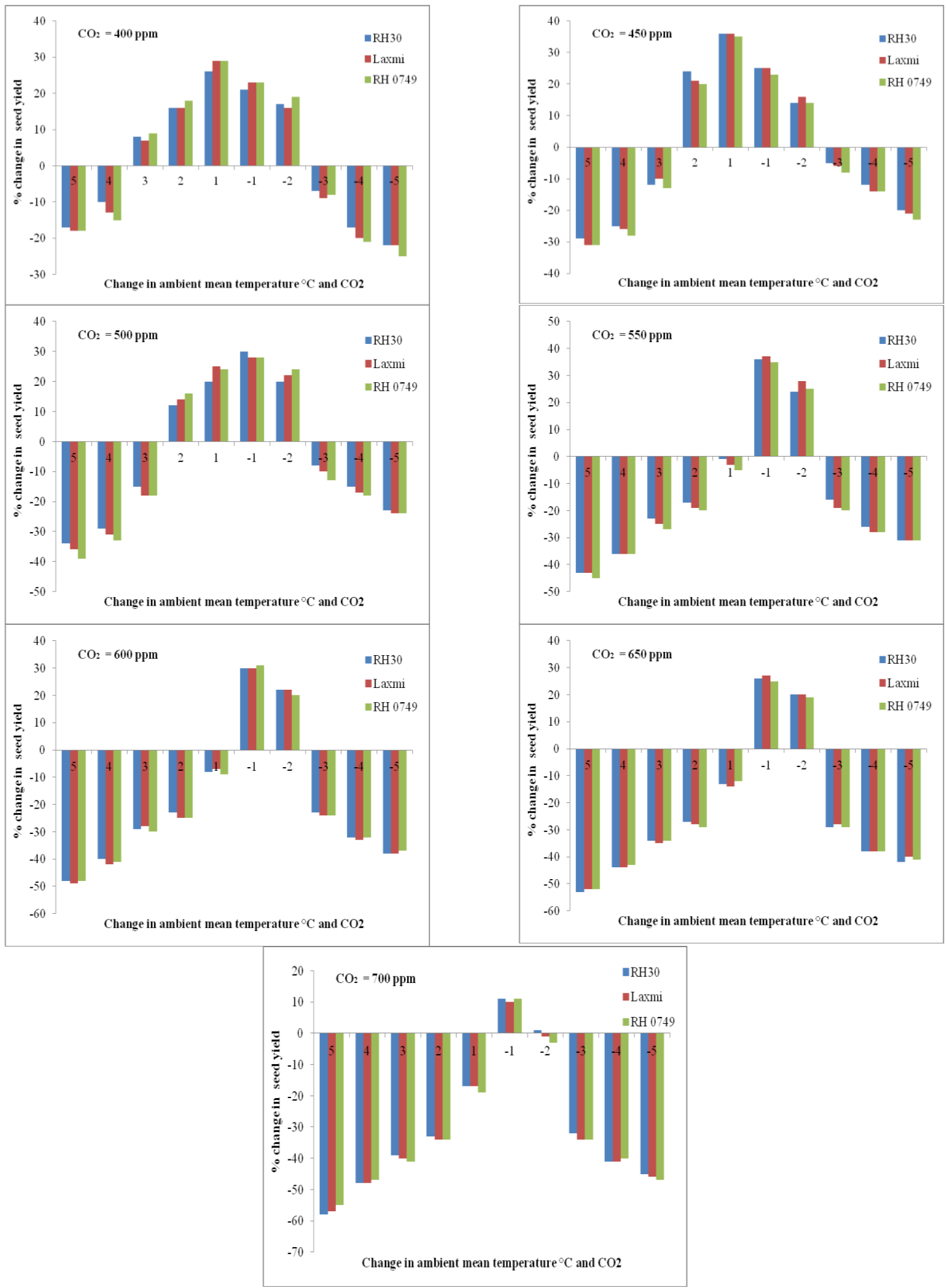


Fig.3 Interaction effect of change in mean ambient temperature $\left({ }^{\circ} \mathrm{C}\right)$ and ranfall change $(\%)$ on simulated mustard seed yield (\% change) using InfoCrop model

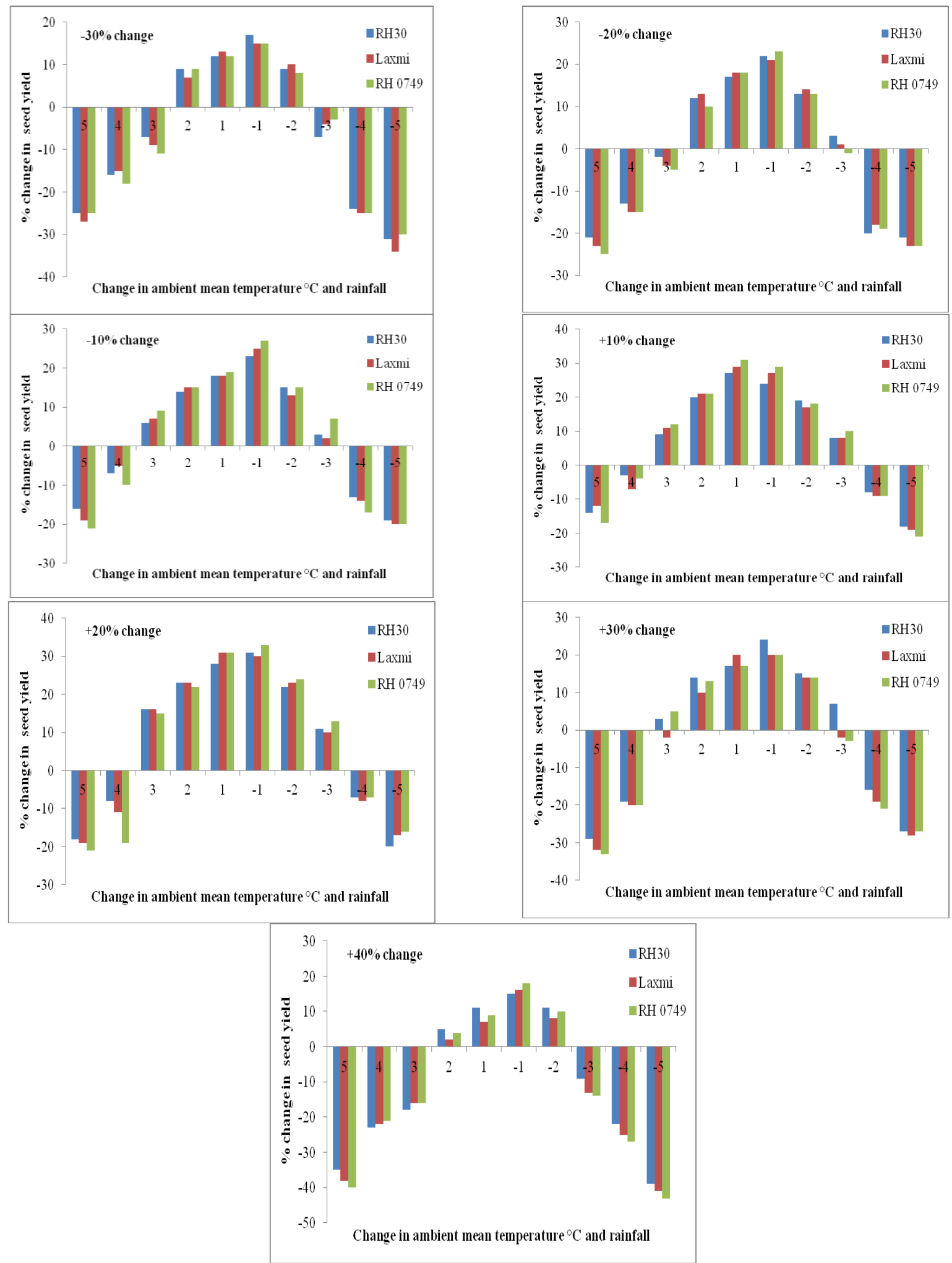


Fig.4 Interaction effect of change in mean ambient temperature $\left({ }^{\circ} \mathrm{C}\right)$ and ranfall change $(\%)$ on simulated mustard seed yield (\% change) using WOFOST model

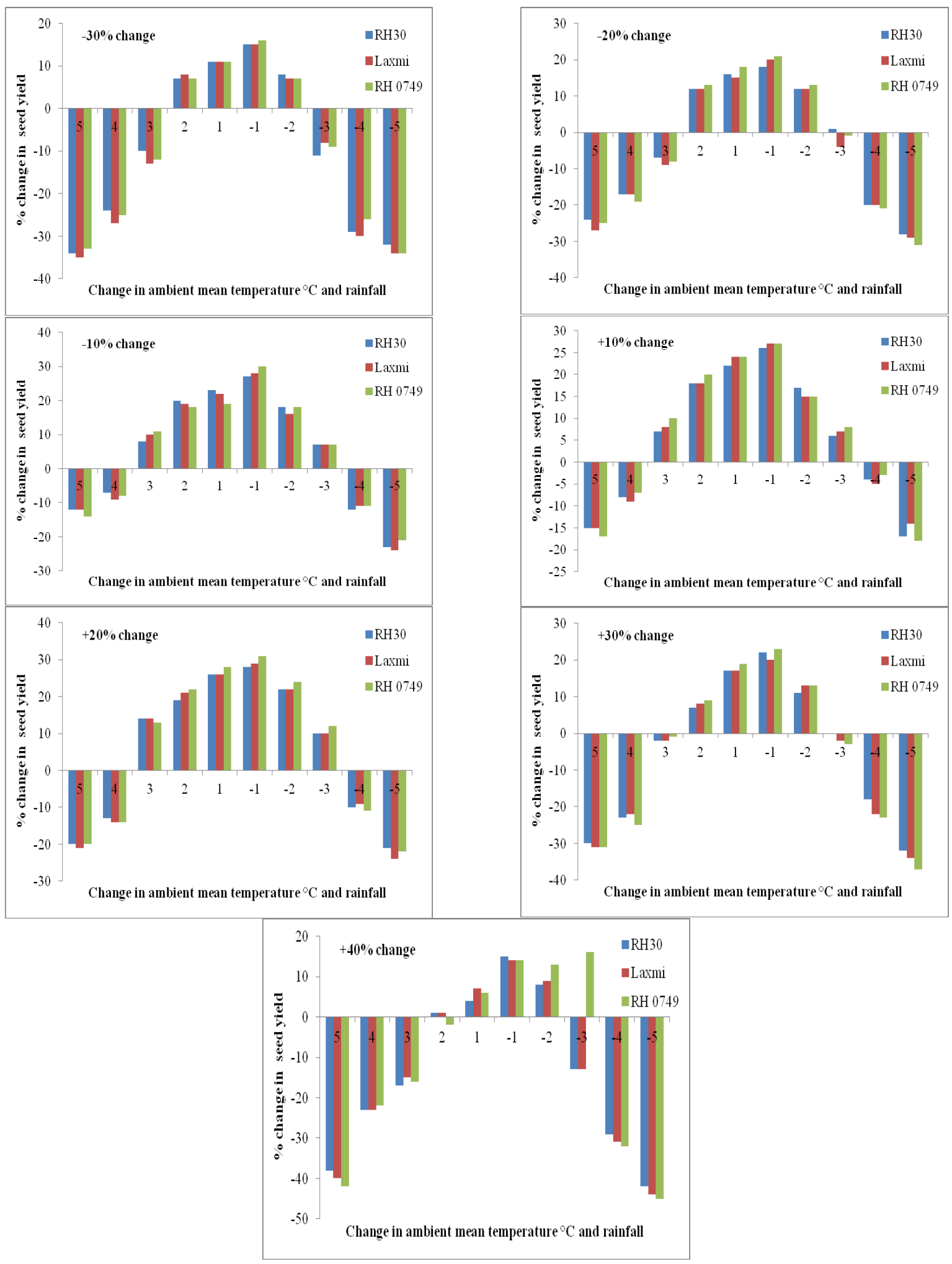


The results indicated that the elevated $\mathrm{CO} 2$ concentrations at 550,600 and $650 \mathrm{ppm}$ could alleviate and positive impact of temperature upto -3 to $+1^{\circ} \mathrm{C}$, however, $700 \mathrm{ppm} \mathrm{CO} 2$ concentration the negative impact of temperature was simulated only at $-1^{\circ} \mathrm{C}$ in all the mustard varieties through both the models. In general an increase in carbon dioxide concentration was found to increase yield while increase in temperature reduced yield (Matthews et al., 2002).

Increase in yield was due to the increase in photosynthesis resulting from higher carbon dioxide concentration. C3 crops (i.e. rice, wheat, mustard) respond more to carbon dioxide enrichment than $\mathrm{C} 4$ crops (i.e. maize, sorghum, sugarcane). But photosynthetically, these plants (C3) are underachievers because, on the one hand, they assimilate atmospheric carbon dioxide into $\mathrm{CH} 2 \mathrm{O}$ but, on the other, part of the potential for $\mathrm{CH} 2 \mathrm{O}$ production is lost by respiration in daylight, releasing carbon dioxide into the atmosphere, a wasteful process termed photorespiration $(\mathrm{Ku}$, 2000).

Several reviews have exposed that the above increase in photosynthetic rates is translated to increase in biomass production and grain yield of mustard crop (Lawlor and Mitchell, 1991; Jablonski et al., 2002). These analyses were match with the findings of Kadam et al., (2014); Akula (2005a); Mukherjee et al., (2011); Ruhil et al., (2015) and Mishra et al., (2015).

\section{Effect of mean ambient temperature and rainfall}

Sensitivity analysis was carried out for combined effect of change in mean ambient temperature and percent change in rainfall (30 to $+40 \%$ ) from actual rainfall of study period using InfoCrop and WOFOST models in Figures 3 and 4. The results revealed that rainfall change of $+10 \%$, less reduction in seed yield was observed either increased or decreased in mean ambient temperature $( \pm 1$ to $\pm 5^{\circ} \mathrm{C}$ ) in all three mustard varieties with both the models. The desirable effects for InfoCrop model were simulated under downscaling of the temperature, the total effect being -18 to $27 \%$ (RH 30), -19 to $29 \%$ (Laxmi) and -21 to $31 \%$ (RH 0749), whereas, using WOFOST model, the effect was -17 to $26 \%$ (RH 30), 15 to $27 \%$ (Laxmi) and -18 to $27 \%$ (RH 0749), respectively.

At $+20 \%$ change in rainfall, using InfoCrop model the net effect on yield was -20 to $31 \%$ (RH 30), -19 to $31 \%$ (Laxmi) and -21 to $33 \%$ (RH 0749), however, the effect seen under using WOFOST model was -21 to $28 \%$ (RH 30 ), -24 to $29 \%$ (Laxmi) and -22 to $31 \%$ (RH $0-749$ ), respectively. By increasing the $20 \%$ rainfall scenario, the increase in yield levels are higher in RH 0749 followed by Laxmi and lowest in RH 30 using both crop simulation models. The higher benefits was obtained at $+20 \%$ rise in rainfall but further decrease or increase $(-30$ to $-10 \%$ and +30 to $+40 \%)$ in rainfall combined with change from \pm 3 to \pm $5^{\circ} \mathrm{C}$ in mean ambient temperature reduced the percent change in mustard yield.

The interaction effect of temperature and rainfall change revealed that the response of the variety RH 0749 was quite high followed by RH 30 and Laxmi.

The percent change in yield decreased in both ways i.e. either increasing or decreasing the mean ambient temperature from mean value. The results indicated that the change in rainfall from -30 to $-10 \%$ and +30 to $+40 \%$ could alleviate and positive impact of temperature upto -2 to $+2^{\circ} \mathrm{C}$ on seed yield by InfoCrop model, however, rainfall change from -10 to $+20 \%$ have positive impact of temperature was simulated from -3 to $+3^{\circ} \mathrm{C}$ on seed yield in all the mustard cultivars by 
using WOFOST model. The results were supported by Catalin et al., (2009); Kadam et al., (2014) and Mishra et al., (2015).

The results of the study described the tolerance power of various mustard cultivars in relation to changed temperature, rainfall and $\mathrm{CO}_{2}$ conditions. The higher per cent of benefits was obtained at 500 ppm but further increase in $\mathrm{CO}_{2}(550,600,650$ and $700 \mathrm{ppm})$ combined with one unit increase in mean ambient temperature reduced the percent change in mustard yield.

The interaction effect of temperature and $\mathrm{CO}_{2}$ concentration revealed that the response of variety Laxmi was quite higher followed by RH 0749 and $\mathrm{RH}$ 30. At highest $\mathrm{CO}_{2}$ concentration (700 ppm), the negative impact of temperature was simulated only at $-1{ }^{\circ} \mathrm{C}$ in all the mustard varieties.

Under increasing of $20 \%$ rainfall scenario, the increase in the yield levels are higher in $\mathrm{RH}$ 0749 followed by Laxmi and RH 30 using both crop simulation models. The higher benefits was obtained at $+20 \%$ rise in rainfall but further decrease or increase ( -30 to $-10 \%$ and +30 to $+40 \%$ ) in rainfall combined with change in mean ambient temperature \pm 3 to \pm $5^{\circ} \mathrm{C}$ reduced the percent change in mustard yield. The interaction effect of temperature and rainfall change revealed that the response of RH 0749 variety was quite higher followed by RH 30 and Laxmi. This is of course, a need to further refine the existing models and also to develop models for more crop species.

\section{Acknowledgement}

The authors thank to Department of Agricultural Meteorology, Chaudhary Charan Singh Haryana Agricultural University, Hisar, India, for providing necessary support for conducting the research as doctoral programme. The authors also thank the
INSPIRE program, Department of Science and Technology, Ministry of science and Technology, India for financial support as $\mathrm{PhD}$ fellowship to the corresponding author.

\section{References}

Adak, T. and Chakravarty, N. V. K (2010). Quantifying the thermal heat requirement of brassica in assessing biophysical parameters under semiarid microenvironment. Inter. J. Bimeteorol., 54 (4): 365-377.

Ainsworth, E. A. and Rogers, A. (2007). The response of photosynthesis and stomatal conductance to rising $\mathrm{CO} 2$ : mechanisms and environmental interactions. Plant Cell Environ., 30: 258-270.

Ainsworth, E. A., Beier, C. and Calfapietra, C. (2008). Next generation of elevated $\mathrm{CO}_{2}$ experiments with crops: a critical investments for feeding the future world. Plant Cell Environ., 31(1):317324.

Akula, B. and Shekh, A.M. (2005). Sensitivity analysis of InfoCrop to weather and non-weather parameters. Ind. J. Plant Physiol., 10(3): 236-240.

Bhaskaran, B., Mitchell, J.F.B., Lavery, J.R. and Lal, M. (1995). Climatic response of the Indian subcontinent to doubled $\mathrm{CO}_{2}$ concentrations. Inter. J. Climatol., 15: 873-892.

Boomiraj, K., Chakrabarti, B., Aggarwal, P. K., Choudhary, R. and Chander, S. (2010). Assessing the vulnerability of Indian mustard to climate change. Agricul., Ecosy. Environ., 138: 265273.

Catalin, L., Baruth, B., Fabio, M., and Anca, L.D. (2009). Adaptation of WOFOST model from CGMS to Romanian conditions. J. Plant Develop., 16: 97102.

Divesh Choudhary, Singh, R., Pannu, R. K., Singh, D., Sheoran P. and Kumar, A. 
(2014). Validation and sensitivity analysis of InfoCrop model v.1.0 for phenology, yield and yield attributing characters of Indian mustard cultivars in Western Haryana region. Journal of Agrometeorology. 16 (Special Issue-I): 159-163.

Gates, W. L., Mltchell, J. F. B., Boer, G. J., Cubash, U., Meleshko, V. P. (1992). Climate modelling, cllmate prediction and model vahdation. In. Houghton, J. T., Callander, B. A., Varney, S. K. (eds.) Climate change 1992. The Supplementary Report to the IPCC Sclenhflc Assessment. Cambridge University Press, Cambridge, p. 99-134.

IPCC, 2013. Working Group I Contribution to the IPCC Fifth Assessment Report Climate Change 2013: The Physical Science Basis, Summary for Policymakers.

www.climatechange2013.org/images/up loads/WGIAR5SPM_Approved27Sep2 013.pdf.

Jablonski, L.M., Wang, X.Z. and Currtis, P.S. (2002). Plant reproduction under elevated $\mathrm{CO}_{2}$ conditions: a metaanalysis of report on 79 crop and wild species. New Phytologist.156: 926.

$\mathrm{Ku}$, M.S.B. (2000). Metabolically Modified Rice Exhibits Superior Photosynthesis and Yield, ISBN New Report. http://www.biotech-info.netmetabolocally.html.

Kumar, G., Adak, T., Chakravarty, N.V.K., Chamola, R., Katina, R. K. and Singh, H. B. (2007). Effect of ambient thermal regime on growth and yield of Brassica cultivars. Brassica. 9 (1-4): 47-52.

Lawlor, D.W. and Mitchell, R.A.C. (1991). The effects of increasing $\mathrm{CO} 2$ on crop photosynthesis and productivity: a review of field studies; commissioned review. Plant, Cell Environ., 14: 807818.

Matthews R.B., and Stephens, W. (2002). Application of crop-soil simulation models in tropical. CABI Publishing. CAB International, Wallingford, Oxon, United Kingdom. pp: 80 -90.

Mishra, S.K., Shekh, A.M., Pandey, V., Yadav, S.B. and Patel, H.R. (2015). Sensitivity analysis of four wheat cultivars to varying photoperiod and temperature at different phenological stages using WOFOST model. $J$. Agromet., 17(1): 74-79.

Mukherjee, J., Singh, L., Singh, G., Bal, S.K., Singh, H. and Kaur, P. (2011) Comparative evaluation of WOFOST and ORYZA2000 models in simulating growth and development of rice in Punjab. J. Agromet., 13: 86-91.

Ram Niwas and Khichar, M.L. (2016). Managing impact of climatic vagaries on the productivity of wheat and mustard in India. Mausam, 67: 205-222.

Ruhil, K., Sheeba, Ahmad, A., Iqbal, M. and Tripathy, B.C. (2015). Photosynthesis and growth responses of mustard (Brassica juncea L. cv Pusa Bold) plants to free air carbon dioxide enrichment (FACE). Protoplasma, 252: 935-946.

\section{How to cite this article:}

Divesh Choudhary, Raj Singh, C.S. Dagar, and Anil Kumar. 2018. Implications Test of Temperature, Rainfall and Carbon Dioxide Combinations on Indian Mustard Using Multi Crop Simulation Models for Western Haryana. Int.J.Curr.Microbiol.App.Sci. 7(02): 1090-1099. doi: https://doi.org/10.20546/ijcmas.2018.702.136 